\title{
Assessment of Continuous Oil and Gas Resources in the Beetaloo Basin, Australia, 2018
}

$U$ of 429 million barrels of continuous oil and 8 trillion cubic feet of continuous gas in the Beetaloo Basin of northern Australia.

\section{Introduction}

The U.S. Geological Survey (USGS) quantitatively assessed the potential for undiscovered, technically recoverable continuous oil and gas resources in the Beetaloo Basin of northern Australia (fig. 1). The Mesoproterozoic Roper Group in the basin contains the Velkerri and Kyalla Formations, two organic-rich source formations that possibly form some of the oldest viable petroleum systems in the world (Jackson and others, 1986; Silverman and Ahlbrandt, 2011; Cox and others, 2016). The shale units of the Velkerri and Kyalla were deposited between 1,400 and 1,300 million years ago (Yang and others, 2018). Limited drilling and production testing have shown that these rocks may contain recoverable oil and gas resources (Close, Cote, and others, 2017). For rocks of this age to potentially contain recoverable oil and gas indicates that throughout the long period between the Mesoproterozoic and the present, there has been limited deformation of the Beetaloo Basin, and generation might have been relatively late in the burial history. However, the tectonic evolution of the Mesoproterozoic Beetaloo Basin is largely unknown, and several hypotheses have been advanced that include rift basin, multiphase intracontinental basin, foreland basin, and epicontinental basin development (Silverman and Ahlbrandt, 2011; Cox and others, 2016; Close, Cote, and others, 2017; Yang and others, 2018). Rocks of the Roper Group have not been thermally stressed beyond the gas-generation window (Close, Baruch, and others, 2017).

\section{Total Petroleum Systems and Assessment Units}

The USGS defined the Proterozoic Velkerri Shale Total Petroleum System (TPS) with the Proterozoic Middle Velkerri Shale Gas Assessment Unit (AU) and the Proterozoic Lower Kyalla Shale TPS with the Proterozoic Lower Kyalla Shale Oil AU and the Proterozoic Lower Kyalla Shale Gas AU. Shales from the middle part of the Velkerri Formation are overpressured and can have as much as 12 weight percent total organic matter, have hydrogen indices as high as 730 milligrams of hydrocarbon per gram of organic carbon, and contain Type I and Type II organic matter (Crick and others, 1988; Warren and others, 1998; Law and others, 2010; McConachie and others, 2015; Revie, 2016; Close, Baruch, and others, 2017). Shales of the lower part of the Kyalla Formation are overpressured and can have as much as 8 weight percent total organic carbon, have hydrogen indices as high as 780 milligrams of hydrocarbon per gram of organic carbon, and contain Type I and Type II organic matter (Law and others, 2010; McConachie and others, 2015; Revie, 2016; Close, Baruch, and others, 2017). The interpretation of the extent of the oil and gas thermal generation windows in these shales is quite variable (Law and others, 2010; Revie, 2016; Close, Baruch, and others, 2017). In this study, the oil and gas thermal windows of Revie (2016) and Close, Baruch, and others (2017) were used in the definition of AU boundaries with the understanding that these boundaries are highly uncertain. The timing of oil and gas generation is also highly uncertain given what little is known of the tectonic evolution, burial history, and paleo-heat flow. Estimates of timing of generation range from essentially syndepositional to early Paleozoic (Crick and others, 1988) or as late as the Mesozoic (Silverman and Ahlbrandt, 2011).

The geologic model for the Proterozoic Middle Velkerri Shale Gas $\mathrm{AU}$ is for oil to have been generated from Type I and Type II organic matter

and largely cracked to gas with some portion of the gas retained within the shales. The geologic model for the Proterozoic Lower Kyalla Shale Oil AU and Proterozoic Lower Kyalla Shale Gas AU is for these shales to have been buried to depths within the oil- and gas-generation windows; some portion of the oil and gas has been retained within the shales following migration. Uncertainty in the assessment is related to the retention of oil and gas in these shales and the mapped extent of the oil and gas thermal generation windows.

The assessment input data are summarized in table 1. There are no geologic analogs for these Mesoproterozoic organic-rich shales, so well drainage areas, success ratios, and estimated ultimate recoveries are roughly based on data ranges from U.S. shale-oil and shale-gas accumulations.

\section{Undiscovered Resources Summary}

The USGS quantitatively assessed the potential for continuous oil and gas resources within the Beetaloo Basin (table 2). The estimated mean totals for undiscovered resources are 429 million barrels of oil (MMBO) with an F95-F5 range from 0 to 1,135 MMBO; 8,044 billion cubic feet of gas (BCFG), or 8 trillion cubic feet of gas, with an F95-F5 range from 0 to 23,749 BCFG; and 278 million barrels of natural gas liquids (MMBNGL) with an F95-F5 range from 0 to 867 MMBNGL.

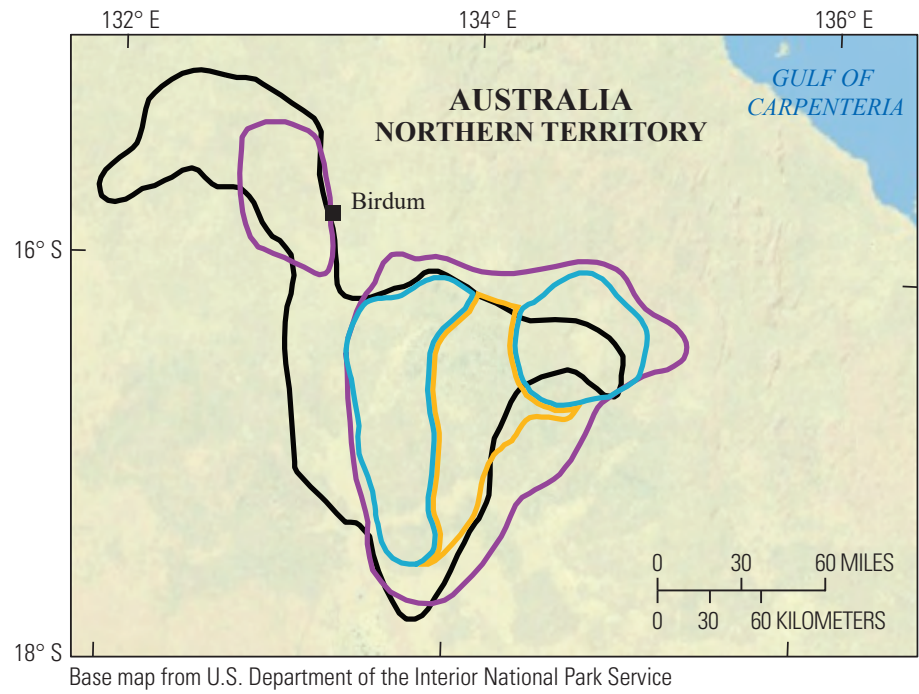

Base map from U.S. Department of the Interior National Park Service

EXPLANATION

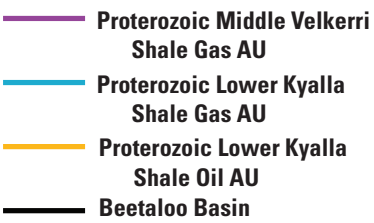

Figure 1. Map showing the location of three continuous assessment units ( $A U s$ ) in the Beetaloo Basin of northern Australia. 
Table 1. Key input data for three continuous assessment units in the Beetaloo Basin, northern Australia.

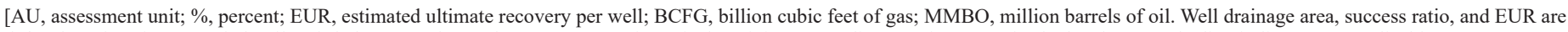
defined partly using U.S. shale-oil and shale-gas analogs. The average EUR input is the minimum, median, maximum, and calculated mean. Shading indicates not applicable]

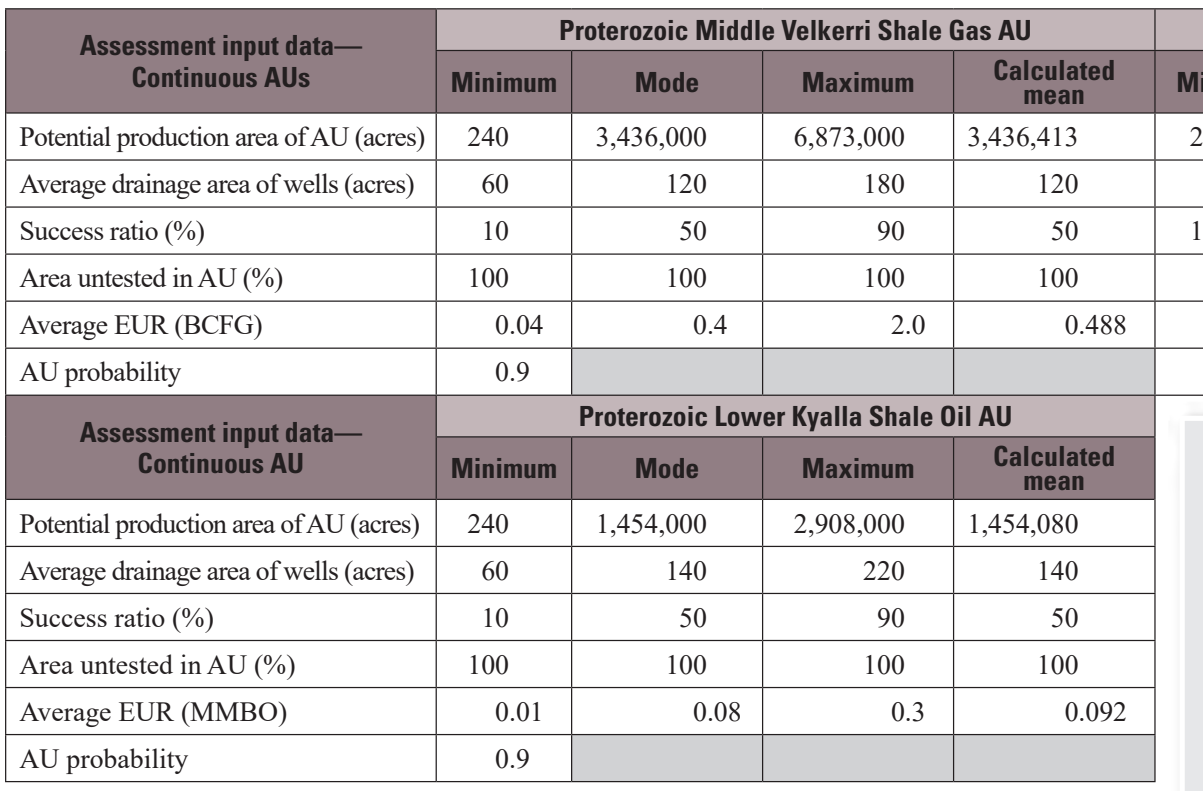

Proterozoic Lower Kyalla Shale Gas AU

\begin{tabular}{|c|c|c|c|}
\hline Minimum & Mode & Maximum & $\begin{array}{c}\text { Calculated } \\
\text { mean }\end{array}$ \\
\hline 240 & $2,686,000$ & $5,372,000$ & $2,686,080$ \\
\hline 60 & 120 & 180 & 120 \\
\hline 100 & 100 & 100 & 100 \\
\hline 10 & 50 & 90 & 50 \\
\hline 0.04 & 0.1 & 1.5 & 0.169 \\
\hline 0.9 & & & \\
\hline
\end{tabular}

\section{Beetaloo Basin Assessment Team}

Christopher J. Schenk, Tracey J. Mercier, Cheryl A. Woodall, Thomas M. Finn, Kristen R. Marra, Michael E. Brownfield, Heidi M. Leathers-Miller, and Ronald M. Drake II

\section{For More Information}

Assessment results are also available at the USGS Energy Resources Program website at https:// energy.usgs.gov.

\section{Table 2. Results for three continuous assessment units in the Beetaloo Basin, northern Australia.}

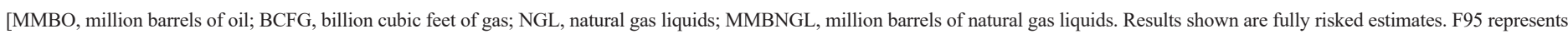

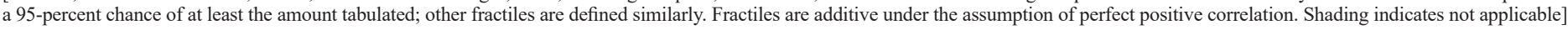

\begin{tabular}{|c|c|c|c|c|c|c|c|c|c|c|c|c|c|c|}
\hline \multirow{3}{*}{$\begin{array}{l}\text { Total petroleum systems } \\
\text { and assessment units (AUs) }\end{array}$} & \multirow{3}{*}{$\begin{array}{c}\text { AU } \\
\text { probability }\end{array}$} & \multirow{3}{*}{$\begin{array}{l}\text { Accumulation } \\
\text { type }\end{array}$} & \multicolumn{12}{|c|}{ Total undiscovered resources } \\
\hline & & & \multicolumn{4}{|c|}{ Oil (MMBO) } & \multicolumn{4}{|c|}{ Gas (BCFG) } & \multicolumn{4}{|c|}{ NGL (MMBNGL) } \\
\hline & & & F95 & $\mathrm{F} 50$ & $\mathrm{~F} 5$ & Mean & F95 & $\mathrm{F} 50$ & $\mathrm{~F} 5$ & Mean & F95 & F50 & F5 & Mean \\
\hline \multicolumn{15}{|c|}{ Proterozoic Velkerri Shale Total Petroleum System } \\
\hline Proterozoic Middle Velkerri Shale Gas AU & 0.9 & Gas & & & & & 0 & 4,631 & 17,544 & 6,155 & 0 & 145 & 617 & 205 \\
\hline \multicolumn{15}{|c|}{ Proterozoic Lower Kyalla Shale Total Petroleum System } \\
\hline Proterozoic Lower Kyalla Shale Gas AU & 0.9 & Gas & & & & & 0 & 982 & 5,490 & 1,631 & 0 & 37 & 227 & 65 \\
\hline Proterozoic Lower Kyalla Shale Oil AU & 0.9 & Oil & 0 & 347 & 1,135 & 429 & 0 & 197 & 715 & 258 & 0 & 6 & 23 & 8 \\
\hline $\begin{array}{l}\text { Total undiscovered } \\
\text { continuous resources }\end{array}$ & & & 0 & 347 & 1,135 & 429 & 0 & 5,810 & 23,749 & 8,044 & 0 & 188 & 867 & 278 \\
\hline
\end{tabular}

\section{References Cited}

Close, D., Baruch, E., Cote, A., Altmann, C., Mohinudeen, F., Richards, B., and Stonier, S., 2017, Unconventional gas potential in the Northern Territory, AustraliaExploring the Beetaloo sub-basin: American Association of Petroleum Geologists, Search and Discovery Article No. 10933, 13 p., accessed October 19, 2018, at http:// www.searchanddiscovery.com/pdfz/documents/2017/10933close/ndx close.pdf.htm $1 ? q=\% 252$ BauthorStrip $\% 253$ Aclose + -isMeetingAbstract $\% 253$ Amtgabsyes.

Close, D., Cote, A., Baruch, E., Altmann, C., Mohinudeen, F., Richards, B., and Ilett, R., 2017, Proterozoic shale gas plays in the Beetaloo Basin and the Amungee NW-1H discovery, in 2017 Annual Geoscience Exploration Seminar, Alice Springs, Northern Territory, Australia, March 28-19, 2017, Proceedings: Northern Territory Geological Survey, p. 91-97, accessed October 19, 2018, at http:/www.paltar.com.au/ AGES2017 DC.pdf.

Cox, G.M., Jarrett, A., Edwards, D., Crockford, P.W., Halverson, G.P., Collins, A.S., Poirier, A., and Li Zheng-Xiang, 2016, Basin redox and primary productivity within the Mesoproterozoic Roper Seaway: Chemical Geology, v. 440, p. 101-114.

Crick, I.H., Boreham, C.J., Cook, A.C., and Powell, T.G., 1988, Petroleum geology and geochemistry of Middle Proterozoic McArthur Basin, Northern Australia II-Assessment of source rock potential: American Association of Petroleum Geologists Bulletin, v. 72, no. 12, p. 1495-1514.

Jackson, M.J., Powell, T.G., Summons, R.E., and Sweet, I.P., 1986, Hydrocarbon shows and petroleum source rocks in sediments as old as $1.7 \times 10^{9}$ years: Nature, v. 322, p. 727-729.

Law, B., Ahlbrandt, T., and Hoyer, D., 2010, Source and reservoir rock attributes of Mesoproterozoic shales, Beetaloo Basin, Northern Territory, Australia: American Association of Petroleum Geologists, Search and Discovery Article No. 110130, 42 p., accessed October 19, 2018, at http://www.searchanddiscovery.com/documents/2010/110130law/ ndx_law.pdf?q= $\% 2$ BauthorStrip $\% 3$ Ahoyer+-isMeetingAbstract $\% 3$ Amtgabsyes.
McConachie, B.A., Stanmore, P., McLean-Hodgson, L., Kushkarina, A., and Lewis, E., 2015, Unconventional gas reservoir productivity in Australian Proterozoic rocks - Studies from the McArthur, Beetaloo, Mount Isa, and Amadeus: American Association of Petroleum Geologists, Search and Discovery Article No. 80501, 33 p., accessed October 19, 2018, at http:/www.searchanddiscovery.com/ documents/2015/80501mcconachie/ndx_mcmonachie.pdf?q=\%2BauthorStrip $\% 3 \mathrm{~A}$ mcconachie+-isMeetingAbstract $\% 3$ Amtgabsyes.

Revie, D., 2016, From the back of the shed to the forefront of exploration-What the NTGS core store is revealing about the Roper Group shales of the greater McArthur Basin, in 2016 Annual Geoscience Exploration Seminar, Alice Springs, Northern Territory, Australia, March 15-16, 2016, Proceedings: Northern Territory Geological Survey, 29 p., accessed October 19, 2018, at https://geoscience.nt.gov. au/gemis/ntgsjspui/handle/1/82743.

Silverman, M., and Ahlbrandt, T., 2011, Mesoproterozoic unconventional plays in the Beetaloo Basin, Australia-The World's oldest petroleum systems: American Association of Petroleum Geologists, Search and Discovery Article No. 10295, 41 p., accessed October 19, 2018, at http://www. searchanddiscovery.com/documents/2011/10295silverman/ndx_silverman. pdf? $\mathrm{q}=\% 2$ BauthorStrip $\% 3$ Asilverman+-isMeetingAbstract $\% 3 \bar{A}$ mtgabsyes.

Warren, J.K., George, S.C., Hamilton, P.J., and Tingate, P., 1998, Proterozoic source rocks-Sedimentology and organic characteristics of the Velkerri Formation, Northern Territory, Australia: American Association of Petroleum Geologists Bulletin, v. 82, no. 3, p. 442-463.

Yang, B., Smith, T.M., Collins, A.S., Munson, T.J., Schoemaker, B., Nicholls, D., Cox, G., Farkas, J., and Glorie, S., 2018, Spatial and temporal variation in detrital zircon age provenance of the hydrocarbon-bearing upper Roper Group, Beetaloo Sub-basin, Northern Territory, Australia: Precambrian Research, v. 304, p. 140-155. 